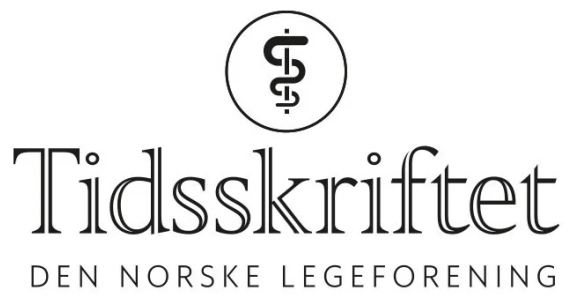

\title{
Downs syndrom eller Down syndrom?
}

SPRÅKSPALTEN

ERLEND HEM

erlend.hem@medisin.uio.no

Erlend Hem er professor dr.med. og fagsjef.

Medisinen er full av eponymer, det vil si ord som er laget etter navn på personer. Hvordan skal de skrives? 


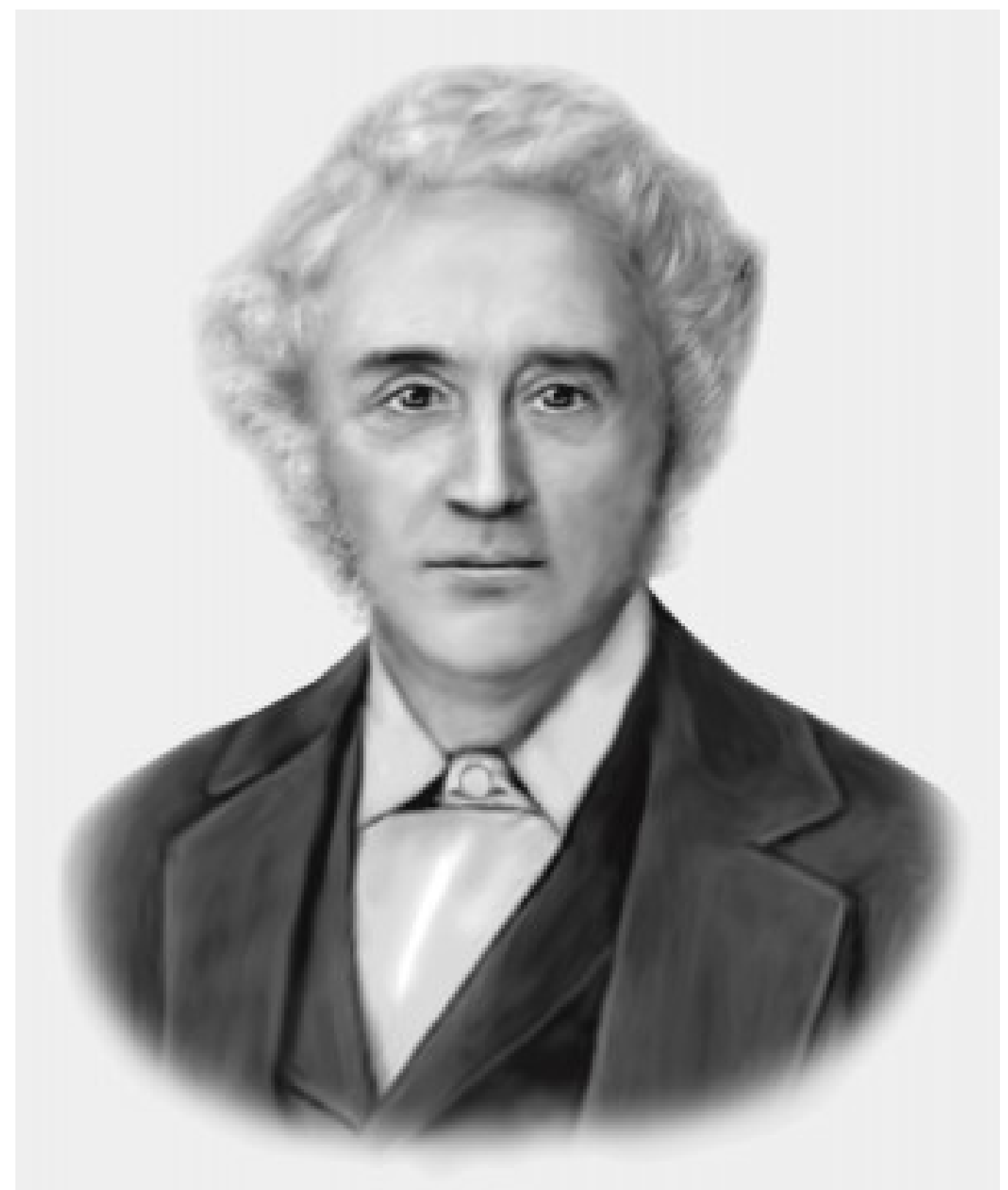

John Langdon Down. Illustrasjon: Colport / Alamy Stock Photo

I medisinen er en lang rekke sykdommer, symptomer, strukturer og operasjoner oppkalt etter personer (1). Ett eksempel er Downs syndrom, som har navn etter den britiske legen John Langdon Down (1828-96) (2 $)$.

På norsk er riktig skrivemåte Downs syndrom, som følger regelen for genitivsform (3).Vi bruker altså genitiv-s etter navnet på personen som noe er oppkalt etter (3). Etter navn som ender på -s, $-x$ og $-z$ brukes apostrof i stedet for genitiv-s, slik som i Homans' tegn, etter kirurgen John Homans (1877-1954), og Simmonds' syndrom, etter patologen Morris Simmonds (1855-1925) (3-5).

\section{Flere skrivemåter}

Skrivemåten av eponymer er omtalt flere ganger i Tidsskriftet. Forståelig nok er dette et tema som setter følelsene i kok hos mange, het det i en artikkel i 1990 ( $\underline{6})$. Flere mente da at den riktige skrivemåten skulle være uten genitiv-s, altså Down syndrom: «Spesielt blant genetikere, nevrologer og pediatere finnes innbitte motstandere av genitiv-s. Disse mener 
at -s etter egennavn må sløyfes fordi den aktuelle personen verken eide syndromet eller hadde sykdommen selv» (므). Men både Norsk språkråd og andre filologer avviste argumentene. De mente at eponymer i medisinen ikke oppfører seg annerledes enn tilsvarende uttrykk i andre fagfelt, for eksempel Ohms lov, og at det er «bred tradisjon for å gi genitiv-s til eponymer i medisinsk nomenklatur» (므).

På engelsk er det mye diskutert om man skal bruke genitiv-s eller ikke (7-11). Down syndrome er vanlig skrivemåte, altså en substantivsammensetning skrevet i to ord. Dette samsvarer med engelske rettskrivningsregler, mens på norsk regnes skrivemåten Down syndrom som feil (므).

Det finnes også andre varianter. På tysk kan man skrive Down-Syndrom, i samsvar med tyske rettskrivningsregler (12). Også på norsk kan man ha slike sammensatte substantiv, slik som Heimlich-manøveren, Le Châtelier-prinsippet og Graaf-generatoren (13). I slike tilfeller erstatter altså bindestreken s-genitiven. Sammensetninger av denne typen er imidlertid mindre vanlige i medisinen. Skrivemåtene Down-syndrom og downsyndrom er lite brukt. I medisinske ordbøker og andre oppslagsverk brukes kun formen Downs syndrom (프).

\section{Konklusjon}

På norsk kan vi skrive Downs syndrom, Down-syndrom og downsyndrom, men formen Downs syndrom er mest brukt.

\section{LITTERATUR}

1. Kåss E, Hem E. Eponym. I: Store medisinske leksikon. https://sml.snl.no/eponym Lest 23.6.2020.

2. Heiberg A. Downs syndrom. I: Store medisinske leksikon. https://sml.snl.no/Downs_syndrom Lest 19.6.2020.

3. Hem E. Homans' tegn og Simmonds' syndrom. Tidsskr Nor Legeforen 2011; 131: 487. [PubMed] [CrossRef]

4. Hem E. Donders eller Donders' metode. Tidsskr Nor Legeforen 2017; 137. doi: 10.4045/tidsskr.17.0632. [PubMed][CrossRef]

5. Vinje FE. Skriveregler. 9. utg. Oslo: Aschehoug, 2011: 56.

6. Stenklev NC. Down eller Downs? Tidsskr Nor Lægeforen 1990; 110: 2388.

7. Jana N, Barik S, Arora N. Current use of medical eponyms-a need for global uniformity in scientific publications. BMC Med Res Methodol 2009; 9: 18. [PubMed][CrossRef]

8. Macaskill MR, Anderson TJ. Whose name is it anyway? Varying patterns of possessive usage in eponymous neurodegenerative diseases. Peer] 2013; 1: e67. [PubMed][CrossRef]

9. Cheng TO. The enigma of 's' in the English language. Int J Cardiol 2013; 168: 3155-6. [PubMed] [CrossRef]

10. Aronson JK. Medical eponyms: taxonomies, natural history, and the evidence. BMJ 2014;349: g7586. [PubMed][CrossRef]

11. Ayesu K, Nguyen B, Harris S et al. The case for consistent use of medical eponyms by eliminating possessive forms. J Med Libr Assoc 2018; 106: 127-9. [PubMed][CrossRef]

12. Downs syndrom. Aktuelt ord. Språkrådet 15.9.2009. https://www.sprakradet.no/Vi-og-vart/hvaskjer/Aktuelt-ord/IDowns-syndromI Lest 19.7.2015.

13. Spørsmål og svar 1: Korleis omsetje Heimlich maneuver? Termposten 2015, nr. 1: 5 . https://www.sprakradet.no/globalassets/vi-og-vart/publikasjoner/termposten/termposten-1-2015.pdf 
Publisert: 12. oktober 2020. Tidsskr Nor Legeforen. DOI: 10.4045/tidsskr.20.0689

(C) Tidsskrift for Den norske legeforening 2023. Lastet ned fra tidsskriftet.no 26. april 2023. 